\title{
PREDICTORS OF THERAPY RESPONSE AND EARLY RECURRENCE IN PATIENTS WITH POTENTIALLY RESECTABLE COLORECTAL LIVER METASTASES TREATED WITH BEVACIZUMAB AND FOLFOX4 AS A CONVERSION THERAPY
}

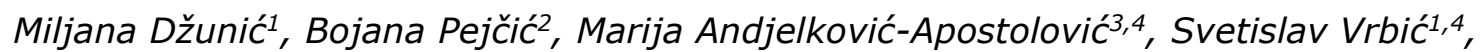 \\ Ivica Pejčićín ${ }^{14}$, Ivan Petković ${ }^{1}$
}

\begin{abstract}
The aim of this study was to define predictive factors for the therapy response and early recurrence after hepatectomy in patients that received conversion therapy FOLFOX4 and bevacizumab for colorectal liver metastases.

This observational retrospective single center analysis included sixty-five patients treated with bevacizumab and FOLFOX4 regimen for potentially resectable colorectal liver metastases. Patients were divided in groups based on objective therapeutic response. Groups with early ( $\leq 3$ months) and late recurrence ( $\geq 12$ months) after hepatectomy were selected. Disease characteristics among groups were compared as well as univariate and multivariate analysis.

Independent risk factor for the lack of therapy response was rectal localization (OR 3.86 [95\% CI 1.31-11.34]; $p=0.014)$. Left colon cancer was independent protective factor for the response absence (OR 0.205 [95\% CI 0.05-0.80]; $p=0.022$ ). Independent predictive factors for early recurrence were synchronous liver disease (OR 18 [95\%CI 2.47-131.28]; $\mathrm{p}=$ 0.004 ) and the number of metastases (OR 2.42 [95\% CI 1.14-5.01]; $p=0.021$ ). In multivariate model only synchronous liver metastases had statistical significance (OR 13.79 [95\% CI 1.54-123.77]; $p=0.019$ ).

Left colon cancer was predictor of response to therapy with bevacizumab and FOLFOX4 and rectal localization was indicative of response absence. Independent risk factors for early recurrence were the number of metastases and synchronous liver involvement.
\end{abstract} Acta Medica Medianae 2019;58(3):72-79.

Key words: colorectal cancer, metastases, liver, predictors

${ }^{1}$ Clinic of Oncology, Clinical Center Niš, Serbia

${ }^{2}$ Oncology and Hematology department, Diakonie Klinikum

Stuttgart, Germany

${ }^{3}$ Public Health Institute Niš, Serbia

${ }^{4}$ University of Niš, Faculty of Medicine, Niš, Serbia

Contact: Miljana Džunić

Blvd dr Zoran Djindjić 48, 18000 Niš, Serbia

E-mail: drmdzunic@gmail.com

\section{Introduction}

Liver metastases are present in $20-25 \%$ of patients at the time of colorectal cancer (CRC) diagnosis and in up to $50 \%$ of patients during the disease course $(1,2)$, making this organ the most common site for CRC dissemination. The aim in planning treatment of colorectal cancer liver metastases (CRLM) should be hepatectomy, which in combination with chemotherapy provides 5 -year overall survival (OS) in up to $67 \%$ of patients and the chance for long term disease free survival and even cure (3-5). Despite curative (R0) metastatic liver resection, up to $70 \%$ of the patients will have a recurrence, in most cases in the first 2 years and predominantly in the liver (6-8).

The fact that in $85 \%$ of patients CRLM are not resectable at the presentation (9) sets the stage for conversion therapy, with the goal of downsizing metastatic deposits so that resection could be performed. Application of conversion therapy with subsequent surgery provides better long term outcome than systemic therapy only (10). In order to achieve the best response and resectability, the most active therapeutic regimen should be used (chemotherapeutic doublet or even triplet, with the addition of targeted agent, bevacizumab or cetuximab in KRAS wild type) (11). Response to preoperative therapy correlates with recurrence free survival (12) and overall survival (14) in patients with initially resecta- 
ble CRLM. In the setting of unresectable liver disease, response to chemotherapy strongly correlates with resection rates (13-15). However, this response is hard to predict.

Long-term survival in patients with surgically removed CRLM is slightly shorter for patients that undergo conversion therapy comparing to those with initially resectable metastases (16). These patients are at higher risk of early recurrence, in case of which the purpose of surgical treatment might be questioned. There were several attempts to define predictive models for the outcome in patients with resected CRLM, but they were not applicable because of mutual diversity (17). For patients with initially unresectable liver metastases there is a strong need for predictors of efficacy of applied therapeutic modalities in order to tailor medical and surgical treatment accordingly.

The aim of this retrospective single center analysis was to access clinicopathological disease characteristics in patients receiving conversion therapy FOLFOX4 and bevacizumab for unresectable CRLM and define predictive factors for therapy response and early recurrence after hepatectomy.

\section{Materials and methods}

From 141 patients medically treated for CRLM at the Clinic of Oncology, Clinical Center Niš, Serbia, in the period from 2010 to 2015, we selected patients with initially unresectable liver-only disease with potential resectability, which have received conversion chemotherapy. Patients with treatment complications leading to discontinuation of therapy, incomplete liver resection ( $R 2$ resection) or a two-stage hepatectomy, operative mortality (non-cancer-related 90-day mortality), follow up shorter than 6 months and incomplete medical record did not participate in the analysis. A total number of included patients was 65.

Performance status of patients according to Eastern Cooperative Oncology Group (ECOG) was 0 - 1. Liver-only metastatic disease was diagnosed by contrast enhanced multislice computed tomography (MSCT) examination of thorax and abdomen. Potential resectability was defined after MSCT scan analysis by an experienced hepatobilliary surgical team. The criteria for unresectability were: not possible upfront R0/R1 resection of all hepatic lesions, < 30\% estimated residual liver volume after resection or metastases in contact with major vessels of the remaining liver. After the regular initial laboratory tests and clinical examination, all patients received chemotherapy (FOLFOX4: oxaliplatin $85 \mathrm{mg} / \mathrm{m}^{2}$ on day 1, leucovorin $200 \mathrm{mg} / \mathrm{m}^{2}$, 5-FU $400 \mathrm{mg} / \mathrm{m}^{2}$ bolus and $600 \mathrm{mg} / \mathrm{m}^{2}$ 22-hour continuous intravenous infusion on days 1 and 2; repeated every 2 weeks) and bevacizumab $\left(5 \mathrm{mg} / \mathrm{m}^{2}\right.$; repeated every 2 weeks). Assessment of therapeutic response according to Response Evaluation Criteria in Solid Tumours (RECIST) and resectability were performed after 4 cycles of chemotherapy on abdominal MSCT scan. Patients with achieved resectability were subjected to surgery and closely followed afterwards.
The following data from the medical records of patients were selected: age, gender, localization and histopathology reports of primary tumor, synchronous (defined as liver involvement at the time of diagnosis or at the surgery of the primary tumor) or metachronous liver disease, number of metastases, number of received chemotherapy cycles, response to therapy and progression free survival (PFS) after hepatectomy.

The group with therapeutic response included patients with complete (CR) or partial response $(P R)$, and the group without response consisted of patients with stable (SD) or progressive (PD) disease. According to the disease free survival after liver resection we selected patients with early recurrence (PFS $\leq 3$ months) and late recurrence (PFS $\geq$ 12 months). Disease characteristics among defined groups were compared.

Statistical analysis was performed using SPSS statistical software, version 16.0 for Windows. Descriptive statistics was used for qualitative and quantitative assessment of the results: absolute numbers, relative numbers (\%), mean value ( ), standard deviation (SD), and median value. The distribution pattern was assessed with Kolmogorov Smirnov test. Independent two-sided t-test $(t)$, nonparametric Mann-Whitney $U$ test, Kruskall Wallace or chisquare $\left(\chi^{2}\right)$ test were applied to compare variables between the groups, where appropriate. Univariate and multivariate logistic regression analysis was used to identify predictors of therapy response and early recurrence. $P$ values of $<0.05$ were considered statistically significant.

\section{Results}

From total number of 65 patients, 41 (63.1\%) were men and 24 (36.9\%) women. The average age of the patients was $59.27 \pm 9.69$ years, the youngest, aged 29, and the oldest, aged 81 . The age difference between men and women was not statistically significant (59.31 \pm 11.17 vs. $59.21 \pm 6.86 ; p=$ 0.969).

Primary tumour was localized in colon in 31 (47.7\%) patients: ascending colon/hepatic flexure in $9(29 \%)$ patients, transversal colon in $3(9.6 \%)$ patients and lienal flexure/descending/sigmoid colon in 19 (61.4\%) patients; 34 (52.3\%) patients had rectal primary. Mucinous adenocarcinoma was diagnosed in $7(10.8 \%)$ patients.

Synchronous and metachronous metastatic liver disease was present in 37 (56.9\%) and 28 (43.1\%) patients, respectively. In 27 (41.5\%) patients 4 or more metastases were registered.

The number of received chemotherapy cycles was ranging from 4 to 12 , mean cycle number was $5.49 \pm 2.24$. Objective therapeutic response (CR/PR) was present in $40(61.5 \%)$ patients, while absent in 25 (38.5\%) patients (PD/SD). Resectability was achieved in $33(50.8 \%)$ patients. Postoperative chemotherapy was applied to $10(30.3 \%)$ patients.

In the group of patients with liver resection, early recurrence was verified in 14 (42.4\%), and late recurrence in 12 (36.4\%) patients. Seven 
patients $(21.2 \%)$ had progression free interval from 4 - 11 months. Median progression free survival was 6.5 [95\% CI 7.49-13.71] months, ranging from 3 to 38 months. Liver was the site of relapse in 23 (69.7\%) patients.

\section{Predictors of therapeutic response}

Groups with and without therapy response were balanced in terms of age $(p=0.389)$ and gender ( $p=0.902)$. The number of received chemotherapy cycles did not differ between groups ( $p=$ 0.670) (Table 1).

Significant difference between patients with and without therapeutic response was found in localization of primary tumour $(p=0.027)$. Independant risk factor for the lack of objective response was rectal localisation of the primary (OR 3.86 [95\% CI 1.31-11.34]; $p=0.014$ ). Left colon cancer (lienal flexure, descending and sigmoid colon) was protective factor for response absence (OR 0.205 [95\% CI $0.05-0.80]$; $p=0.022$ ) meaning that it was pre- dictive of therapy response. Multivariate analysis was performed with variables which proved to be statistically independent factors. Neither of two variables brought statistically significant contribution (Table 1).

\section{Predictors of early recurrence}

In the group with early recurrence synchronous liver disease was significantly more frequent ( $p$ $=0.002$ ) and these patients had significantly more metastases ( $p=0.013$ ) compared to the late recurrence group. Independent risk factors for early relapse were synchronous CRLM (OR 18 [95\% CI 2.47-131.28]; $p=0.004)$ and the number of metastases (OR 2.42 [95\% CI 1.14-5.01]; p = 0.021) (Table 2).

Multivariate model included variables that appeared to be statistically independent factors. Unique statistically significant contribution to the model was provided only by synchronous CRLM (OR 13.79 [95\% CI 1.54-123.77]; $p=0.019$ ) (Table 2).

Table 1. Demographic and clinicopathologic factors according to objective therapeutic response

\begin{tabular}{|c|c|c|c|c|c|c|c|c|}
\hline & & $\mathrm{N}=40$ & $\mathrm{~N}=25$ & \multirow{2}{*}{$\mathrm{p}$} & \multicolumn{2}{|c|}{ Univariate analysis } & \multicolumn{2}{|c|}{ Multivariate analysis } \\
\hline \multicolumn{2}{|c|}{ Factor } & $\mathrm{CR} / \mathrm{PR}$ & SD/PD & & OR(95\%CI) & $p$ & OR(95\%CI & $\mathrm{p}$ \\
\hline \multirow{2}{*}{ Gender n (\%) } & Men & $\begin{array}{c}25 \\
(62.5)\end{array}$ & $\begin{array}{c}16 \\
(64.0)\end{array}$ & \multirow{2}{*}{0.902} & & & & \\
\hline & Women & $\begin{array}{c}15 \\
(37.5)\end{array}$ & $\begin{array}{c}9 \\
(36.0)\end{array}$ & & & & & \\
\hline \multicolumn{2}{|c|}{ Age $\bar{x} \pm S D$} & $\begin{array}{c}60.07 \\
\pm 8.85\end{array}$ & $\begin{array}{c}57.87 \\
\pm 11.06\end{array}$ & 0.389 & & & & \\
\hline \multirow{4}{*}{$\begin{array}{l}\text { Localization } \\
\text { n (\%) }\end{array}$} & $\begin{array}{l}\text { Ascending } \\
\text { colon and } \\
\text { hepatic fl. }\end{array}$ & $\begin{array}{c}5 \\
(12.5)\end{array}$ & $\begin{array}{c}4 \\
(16.0)\end{array}$ & \multirow{4}{*}{0.027} & $\begin{array}{c}1.33 \\
(0.32-5.52)\end{array}$ & 0.629 & & \\
\hline & $\begin{array}{l}\text { Transversal } \\
\text { colon }\end{array}$ & $\begin{array}{c}3 \\
(7.5)\end{array}$ & $\begin{array}{c}0 \\
(0.0)\end{array}$ & & $\begin{array}{c}0.001 \\
(0.01-0.02)\end{array}$ & 0.999 & & \\
\hline & $\begin{array}{l}\text { Lienal fl., } \\
\text { descending } \\
\text { and sigmoid } \\
\text { colon }\end{array}$ & $\begin{array}{c}16 \\
(40.0)\end{array}$ & $\begin{array}{c}3 \\
(12.0)\end{array}$ & & $\begin{array}{c}0.205 \\
(0.05-0.80)\end{array}$ & 0.022 & $\begin{array}{c}0.37 \\
(0.07-2.1)\end{array}$ & 0.264 \\
\hline & Rectum & $\begin{array}{c}16 \\
(40.0) \\
\end{array}$ & $\begin{array}{c}18 \\
(72.0)\end{array}$ & & $\begin{array}{c}3.86 \\
(1.31-11.34) \\
\end{array}$ & 0.014 & $\begin{array}{c}2.25 \\
(0.57-8.91) \\
\end{array}$ & 0.248 \\
\hline \multirow{2}{*}{$\begin{array}{l}\text { Time of } \\
\text { detection } \\
\mathrm{n}(\%)\end{array}$} & Synchronous & $\begin{array}{c}22 \\
(55.0)\end{array}$ & $\begin{array}{c}15 \\
(60.0)\end{array}$ & \multirow{2}{*}{0.692} & & & & \\
\hline & Metachronous & $\begin{array}{c}18 \\
(45.0)\end{array}$ & $\begin{array}{c}10 \\
(40.0)\end{array}$ & & & & & \\
\hline \multicolumn{2}{|c|}{ Number of metastases $\bar{x} \pm S D$} & $\begin{array}{r}3.22 \\
\pm 1,46 \\
\end{array}$ & $\begin{array}{c}3.40 \\
\pm 1.58 \\
\end{array}$ & 0.705 & & & & \\
\hline \multicolumn{2}{|c|}{ Mucinous histology n (\%) } & $\begin{array}{c}3 \\
(7.5)\end{array}$ & $\begin{array}{c}4 \\
(16.0)\end{array}$ & 0.282 & & & & \\
\hline \multicolumn{2}{|c|}{ Number of cycles $\bar{x} \pm S D$} & $\begin{array}{c}5.55 \\
\pm 2.07\end{array}$ & $\begin{array}{c}5.40 \\
\pm 2.50\end{array}$ & 0.670 & & & & \\
\hline
\end{tabular}


Table 2. Demographic and clinicopathologic factors according to time to recurrence

\begin{tabular}{|c|c|c|c|c|c|c|c|c|}
\hline & & $N=14$ & $N=12$ & \multirow[b]{2}{*}{$\mathrm{p}$} & \multicolumn{2}{|c|}{ Univariate analysis } & \multicolumn{2}{|c|}{ Multivariate analysis } \\
\hline \multicolumn{2}{|c|}{ Factor } & $\begin{array}{l}\mathrm{PFS} \leq 3 \\
\text { months }\end{array}$ & $\begin{array}{l}P F S \geq 12 \\
\text { months }\end{array}$ & & OR(95\%CI) & $\mathrm{p}$ & OR(95\%CI) & $\mathrm{p}$ \\
\hline \multirow{2}{*}{ Gender n (\%) } & Men & $\begin{array}{c}6 \\
(42.8) \\
\end{array}$ & $\begin{array}{c}7 \\
(58.3) \\
\end{array}$ & \multirow{2}{*}{0.578} & & & & \\
\hline & Women & $\begin{array}{c}8 \\
(57.2)\end{array}$ & $\begin{array}{c}5 \\
(41.7) \\
\end{array}$ & & & & & \\
\hline \multicolumn{2}{|c|}{ Age $\bar{x} \pm$ SD } & $\begin{array}{c}58.14 \\
\pm 9.24 \\
\end{array}$ & $\begin{array}{r}63.77 \\
\pm 8.92 \\
\end{array}$ & 0.12 & & & & \\
\hline \multirow{4}{*}{$\begin{array}{c}\text { Localization } \\
\text { n (\%) }\end{array}$} & $\begin{array}{l}\text { Ascending } \\
\text { colon and } \\
\text { hepatic fl. }\end{array}$ & $\begin{array}{c}3 \\
(21.4)\end{array}$ & $\begin{array}{c}0 \\
(0.0)\end{array}$ & \multirow{4}{*}{0.276} & & & & \\
\hline & $\begin{array}{l}\text { Transversal } \\
\text { colon }\end{array}$ & $\begin{array}{c}0 \\
(0.0)\end{array}$ & $\begin{array}{c}1 \\
(8.3)\end{array}$ & & & & & \\
\hline & $\begin{array}{l}\text { Splenic fl., } \\
\text { descending } \\
\text { and sigmoid } \\
\text { colon }\end{array}$ & $\begin{array}{c}5 \\
(35.7)\end{array}$ & $\begin{array}{c}5 \\
(41.7)\end{array}$ & & & & & \\
\hline & Rectum & $\begin{array}{c}6 \\
(42.9)\end{array}$ & $\begin{array}{c}6 \\
(50.0)\end{array}$ & & & & & \\
\hline \multirow{2}{*}{$\begin{array}{c}\text { Time of } \\
\text { detection } \\
n(\%)\end{array}$} & Synchronous & $\begin{array}{c}12 \\
(85.7)\end{array}$ & $\begin{array}{c}3 \\
(25.0)\end{array}$ & \multirow{2}{*}{0.002} & $\begin{array}{c}18 \\
(2.47-131.28)\end{array}$ & 0.004 & $\begin{array}{c}13.79 \\
(1.54-123.77)\end{array}$ & 0.019 \\
\hline & Metachronous & $\begin{array}{c}2 \\
(14.3)\end{array}$ & $\begin{array}{c}9 \\
(75.0) \\
\end{array}$ & & & & & \\
\hline \multicolumn{2}{|c|}{ Number of metastases $\bar{x} \pm S D$} & $\begin{array}{c}3.78 \\
\pm 1,36\end{array}$ & $\begin{array}{c}2.33 \\
\pm 1.15 \\
\end{array}$ & 0.013 & $\begin{array}{c}2.42 \\
(1.14-5.01)\end{array}$ & 0.021 & $\begin{array}{c}2.17 \\
(0.89-5.31)\end{array}$ & 0.088 \\
\hline \multicolumn{2}{|c|}{ Mucinous histology n (\%) } & $\begin{array}{c}2 \\
(14.3)\end{array}$ & $\begin{array}{c}0 \\
(0.0) \\
\end{array}$ & 0.173 & & & & \\
\hline \multicolumn{2}{|c|}{ Number of cycles $\bar{x} \pm S D$} & $\begin{array}{c}5.86 \\
\pm 2.35\end{array}$ & $\begin{array}{c}5.41 \\
\pm 2.10\end{array}$ & 0.347 & & & & \\
\hline
\end{tabular}

\section{Discussion}

CRC is a heterogeneous disease which is reflected by different response to therapy and variable outcomes. It has recently been reported that localization of the primary tumour is independent prognostic factor in metastatic CRC (18). Patients with metastatic right colon cancer (RCC) have significantly lower OS compared to the patents with localization of the primary tumour in left colon (LCC) (1821). Additionally, different effects of chemotherapy regimens and targeted agents have been noticed between those two entities. LCC patients have more benefit, in terms of PFS and OS, when treated with combination of irinothecan and 5-fluorouracyl compared to RCC patients, while the combination of irinotecan and oxaliplatin has similar effects for both localizations (21). It is widely reported that LCC patients benefit more from cetuximab (22-23) and bevacizumab $(24,25)$ therapy.

Significant differences at the molecular level exist between RCC and LCC (26). According to recent consensus, four biologically homogenous subtypes of CRC were defined, based on molecular and genetic characteristics: MSI immune (hypermutated, microsatellite unstable, with strong immune activation); Canonical (epithelial, chromosomally unstable, with marked WNT and MYC signalling); Metabolic (epithelial, with evident metabolic dysregulation); and Mesenchymal (prominent TGF- $\beta$ activation, stromal invasion and angiogenesis) (27).

In present study, LCC was identified as predictor of objective therapy response, since it lowers the risk for PD/SD (OR 0.205 [95\% CI 0.05-0.80]; p $=0.022$ ). Conversely, rectal primary presents negative predictive factor for response to bevacizumab and FOLFOX4 therapy, since it represents a risk factor for PD/SD (OR 3.86 [95\% CI 1.31-11.34]; p $=0.014)$. It is probable that some molecular features of the tumor that interfere with therapy response can be linked to tumor localization, which may be the reason for all these apparent differences. For the confirmation of this hypothesis, further molecular studies should be conducted. For the time being, simple information about localization of the primary might be helpful when it comes to treatment. However, neither of these factors showed statistical significance in multivariate analysis.

Mucinous adenocarcinoma accounts for 10$15 \%$ of colorectal cancers (28). Prognostic effects of this specific histopathological type are not clearly stated, and the results are ambiguous. In comparison to adenocarcinoma, mucinous type is associated with young age, advance tumor stage, females, as 
well as with MSI ad activating mutations of BRAF gene (29). These genetic features are predictive of poor outcome. In this study, $10.8 \%$ of patients had mucinous adenocarcinoma, and we could not associate this factor with the response to bevacizumab and FOLFOX4 therapy $(p=0.282)$.

With the development of powerful chemotherapeutics and new surgical techniques, indications for hepatectomy in CRLM are rising (30). Thus, a problem with early recurrence is emerging. In case of early relapse, the purpose of hepatectomy is quesstioned, and this standard approach might be challenged. It is widely reported that early recurrence after CRLM resection is a poor prognostic factor of survival (30-32).

Two recent large observational studies considered predictive factors for early recurrence in patients with surgical resection of CRLM. Imai et al. (30) defined early recurrence within 8 months, based on the minimum $p$ value for survival after initial recurrence. In the subset of patients who received preoperative chemotherapy, $43 \%$ had initially unresectable liver disease. Early recurrence was present in $45 \%$ of patients, and independent predictive factors were age $\leq 57$ years, more than 1 chemotherapy line, progression on last line of chemotherapy and CA $19-9$ levels $>60 \mathrm{U} / \mathrm{ml}$. In the study of Vigano et al. (32), relapse within 6 months after liver resection was defined as early. Independent risk factors for early recurrence in the subset of patients that received preoperative chemotherapy were T3-4 primary tumor, associated radiofrequent ablation, no objective response to chemotherapy and the lack of postoperative chemotherapy. Both studies identified number of metastases as a predictor of early relapse, the first with more than 3 metastases at the diagnosis (32), the later with more than 3 metastases at hepatectomy (30). Synchronous CRLM was independent predictive factor for early relapse for the whole study population (32), but not in the preoperatively treated patients $(30,32)$. However, neither of these two studies separately analyzed the predictors of early relapse for the patients with initially unresectable CRLM.

In the present study, the limit for the early recurrence has been set to be 3 months while for these patients surgery seems to be of minimal benefit. Independent predictive factors for early recurrence compared to late recurrence were the number of metastases in univariate (OR 2.42 [95\% CI 1.14$5.01] ; p=0.021)$, and synchronous liver disease in univariate (OR 18 [95\% CI 2.47-131.28]; $p=0.004$ ) as well as multivariate analysis (OR 13.79 [95\%CI 1.54-123.77]; $p=0.019)$. Patients with synchronous CRLM and large tumor burden have very aggressive disease, so early recurrence after surgery is more common. In such cases, liver resection has negligible contribution to PFS, and if not avoided, should be supported with different means of systemic treatment.

The shortcomings of this study were low number of patients, retrospective nature and lesser number of examined factors. However, this is, according to our knowledge, the first report of predictive factors in the setting of initially unresectable CRLM, and predictors of chemotherapy response were also assessed as an important part of these patients' treatment.

When it comes to treatment of unresectable CRLM, assessing the predictive factors for response to conversion therapy may be helpful in choosing the most potent combination therapy for CRLM downsizing or redefining the goal of treatment (palliative or curative). Knowing predictors of early relapse might be of assistance in selecting the patients with real benefit from liver surgery and adapting postoperative chemotherapy accordingly. The cooperation between medical and surgical oncologists is essential in this patient subgroup in order to get the most of the multimodality treatment.

\section{Conclusion}

This study identified localization of primary tumor in the rectum as an independent risk factor for the lack of response, and left colon cancer as a predictor of response to therapy with bevacizumab and FOLFOX4 in univariate analysis. Independent risk factors for early recurrence were the number of metastases in univariate and synchronous CRLM in univariate and multivariate analysis. 


\section{References}

1. Nordlinger $B$, Van Cutsem $E$, Rougier $P$, Köhne $\mathrm{CH}$, Ychou M, Sobrero A, et al. Does chemotherapy prior to liver resection increase the potential for cure in patients with metastatic colorectal cancer? A report from the European Colorectal Metastases Treatment Group. Eur J Cancer 2007; 43:2037-45. [PubMed] [CrossRef]

2. Van den Eynde M, Hendlisz A. Treatment of colorectal liver metastases: A review. Rev Recent Clin Trials 2009; 4:56-62. [PubMed] [CrossRef]

3. Simmonds PC, Primrose JN, Colquitt JL, Garden OJ, Poston GJ, Rees M. Surgical resection of hepatic metastases from colorectal cancer. A systematic review of published studies. Br J Cancer 2006; 94:982-99.

[PubMed] [CrossRef]

4. Morris EJ, Forman D, Thomas JD, Quirke P, Taylor EF, Fairley $L$, et al. Surgical managements and outcomes of colorectal cancer liver metastases. Br J Surg 2010; 97:1110-8. [PubMed] [CrossRef]

5. Adam R, De Gramont A, Figueras J, Guthrie A, Kokudo $N$, Kunstlinger $F$, et al. The oncosurgery approach to managing liver metastases from colorectal cancer: A multidisciplinary international consensus. The Oncologist 2012; 17:1225-39. [PubMed] [CrossRef]

6. Choti MA, Sitzman JV, Tiburi MF, Sumetchotimetha W, Rangsin $R$, Schulick $R D$, et al. Trends in long term survival following liver resection for hepatic colorectal metastases. Ann Surg 2002; 235:759-66. [PubMed] [CrossRef]

7. De Jong MC, Pulitano C, Ribero D, Strub J, Mentha G, Schulick RD, et al. Rates and patterns of recurrence following curative intent surgery for colorectal liver metastasis: An international multi-institutional analysis of 1669 patients. Ann Surg 2009; 250:440-8. [PubMed] [CrossRef]

8. D'Angelica M, Kornprat $P$, Gonen M, De Matteo RP, Fong $\mathrm{Y}$, Blumgart $\mathrm{LH}$, et al. Effect on outcome of recurrence patterns after hepatectomy for colorectal metastases. Ann Surg Oncol 2011; 18:1096-103. [PubMed] [CrossRef]

9. Poston GJ, Figueras J, Giuliante F, Nuzzo G, Sobrero $A F$, Gigot JF, et al. Urgent need for a new staging system in advanced colorectal cancer. J Clin Oncol 2008; 26:4828-33. [PubMed] [CrossRef]

10. Adam R, Delvart V, Pascal G, Valeanu A, Castaing D, Azoulay $D$, et al. Rescue surgery for unresectable colorectal liver metastases downstaged by chemotherapy: a model to predict long-term survival. Ann Surg 2004; 240:644-57. [PubMed] [CrossRef]

11. Van Cutsem E, Cervantes A, Adam R, Sobrero A, Van Krieken JH, Aderka D, et al. ESMO consensus guidelines for the management of patients with metastatic colorectal cancer. Ann Oncol 2016; 27:1386-422. [PubMed] [CrossRef]

12. Gruenberger B, Scheithauer W, Punzengruber $R$, Zielinski C, Tamandl D, Gruenberger T. Importance of response to neoadjuvant chemotherapy in potentially curable colorectal cancer liver metastases. BMC Cancer 2008; 8:120. [PubMed] [CrossRef]

13. Gruenberger T, Kaczirek K, Bergmann M, Zielinski CC, Gruenberger B. Progression-free survival in a Phase II study of perioperative bevacizumab plus Xelox in patients with potentially curable metastatic colorectal cancer. ASCO annual meeting proceedings 2008; 26: 4073. [CrossRef]

14. Van Cutsem $E$, Nordlinger $B$, Adam $R$, Köhne $\mathrm{CH}_{\text {, }}$ Pozzo C, Poston G, et al. Towards a pan-European consensus on the treatment of patients with colorectal liver metastases. Eur J Cancer 2006; 42:2212-21. [PubMed] [CrossRef]

15. Folprecht G, Gruenberger T, Bechstein WO, Raab HR, Lordick F, Hartmann JT, et al. Tumour response and secondary resectability of colorectal liver metastases following neoadjuvant chemotherapy with cetuximab: the CELIM randomised phase 2 trial. Lancet Oncol 2010; 11:38-47. [PubMed] [CrossRef]

16. De Greef K, Rolfo C, Russo A, Chapelle T, Bronte G, Passiglia $F$, et al. Multidisciplinary management of patients with liver metastasis from colorectal cancer. World J Gastroenterol 2016; 22:7215-25.

[PubMed] [CrossRef]

17. Spelt L, Andersson B, Nilsson J, Andersson R. Prognostic models for outcome following liver resection for colorectal cancer metastases: A systematic review. Eur J Surg Oncol 2012; 38:16-24. [PubMed] [CrossRef]

18. Suttie SA, Shaikh I, Mullen R, Amin AI, Daniel T, Yalamarthi S. Outcome of right- and left-sided colonic and rectal cancer following surgical resection. Colorectal Dis. 2011; 13:884-9. [PubMed] [CrossRef]

19. Price TJ, Beeke C, Ullah S, Padbury R, Maddern G, Roder $D$, et al. Does the primary site of colorectal cancer impact outcomes for patients with metastatic disease? Cancer 2015; 121:830-5. [PubMed] [CrossRef]

20. Meguid RA, Slidell MB, Wolfgang CL, Chang DC, Ahuja $N$. Is there a difference in survival between right- versus left-sided colon cancers? Ann Surg Oncol 2008; 15:2388-94. [PubMed] [CrossRef]

21. Modest DP, Schulz C, von Weikersthal LF, Quietzsch $D$, von Einem JC, Schalhorn A, et al. Outcome of patients with metastatic colorectal cancer depends on the primary tumor site (midgut vs. hindgut): analysis of the FIRE1-trial (FuFIRI or mIROX as first-line treatment). Anticancer Drugs 2014; 25:212-8. [PubMed] [CrossRef]

22. von Einem JC, Heinemann V, von Weikersthal LF, Vehling-Kaiser U, Stauch M, Hass HG, et al. Left-sided primary tumors are associated with favorable prognosis in patients with KRAS codon 12/13 wild-type metastatic colorectal cancer treated with cetuximab plus chemotherapy: an analysis of the AIO KRK-0104 trial. J Cancer Res Clin Oncol 2014; 140:1607-14. [PubMed] [CrossRef]

23. Brulé SY, Jonker DJ, Karapetis CS, O'Callaghan CJ, Moore MJ, Wong R, et al. Location of colon cancer (right-sided versus left-sided) as a prognostic factor and a predictor of benefit from cetuximab in NCIC CO.17. Eur ] Cancer 2015; 51:1405-14. [PubMed] [CrossRef]

24. Boisen MK, Johansen JS, Dehlendorff C, Larsen JS, Osterlind $\mathrm{K}$, Hansen J, et al. Primary tumor location and bevacizumab effectiveness in patients with metastatic colorectal cancer. Ann Oncol 2013; 24: 2554-9. [PubMed] [CrossRef]

25. Volz NB, Stintzing S, Zhang W, Yang D, Ning Y, Wakatsuki T, et al. Genes involved in pericyte-driven tumor maturation predict treatment benefit of first-line FOLFIRI plus bevacizumab in patients with metastatic colorectal cancer. Pharmacogenomics J 2015; 15:6976. [PubMed] [CrossRef]

26. Shen $\mathrm{H}$, Yang J, Huang $\mathrm{Q}$, Jiang MJ, Tan $Y N$, Fu JF, et al. Different treatment strategies and molecular 
features between right-sided and left-sided colon cancers. World J Gastroenterol 2015; 21:6470-8.

[PubMed] [CrossRef]

27. Guinney J, Dienstmann $R$, Wang $B$, de Reyniès $A$, Schlicker A, Soneson C, et al. The consensus molecular subtypes of colorectal cancer. Nat Med 2015; 21:1350-6. [PubMed] [CrossRef]

28. Lin J, Qiu M, Xu R, Dobs AS. Comparison of survival and clinicopathologic features in colorectal cancer among African American, Caucasian, and Chinese patients treated in the United States: results from the surveillance epidemiology and end results (SEER) database. Oncotarget 2015; 6:33935-43.

[PubMed] [CrossRef]

29. Verhulst J, Ferdinande L, Demetter P, Ceelen W. Mucinous subtype as prognostic factor in colorectal cancer: a systematic review and meta-analysis. J Clin Pathol 2012; 65:381-8. [PubMed] [CrossRef]
30. Imai K, Allard MA, Benitez CC, Vibert E, Sa Cunha A, Cherqui $D$, et al. Early recurrence after hepatectomy for colorectal liver metastases: what optimal definition and what predictive factors? Oncologist 2016; 21: 887-94. [PubMed] [CrossRef]

31. Takahashi S, Konishi M, Nakagohri T, Gotohda N, Saito N, Kinoshita T. Short time to recurrence after hepatic resection correlates with poor prognosis in colorectal hepatic metastasis. Jpn J Clin Oncol. 2006; 36:368-75. [PubMed] [CrossRef]

32. Vigano L, Capussotti L, Lapointe R, Barroso E, Hubert C, Giuliante F, et al. Early recurrence after liver resection for colorectal metastases: risk factors, prognosis, and treatment. A LiverMetSurvey-based study of 6,025 patients. Ann Surg Oncol 2014; 21:1276-86. [PubMed] [CrossRef] 


\title{
PREDIKTORI TERAPIJSKOG ODGOVORA I RANOG RELAPSA KOD PACIJENATA SA POTENCIJALNO RESEKTABILNIM METASTAZAMA KOLOREKTALNOG KARCINOMA U JETRI LEČENIH KONVERZIONOM TERAPIJOM BEVACIZUMAB I FOLFOX4
}

\author{
Miljana Džunić1, Bojana Pejčić2 ${ }^{2}$ Marija Anđelković-Apostolovićc 3,4 , Svetislav Vrbić1,4, \\ Ivica Pejčićc ${ }^{1,4}$, Ivan Petković ${ }^{1}$
}

\author{
${ }^{1}$ Klinika za onkologiju, Klinički centar Niš, Niš, Srbija \\ ${ }^{2}$ Odeljenje za onkologiju i hematologiju, Opšta klinika, Štutgart, Nemačka \\ ${ }^{3}$ Institut za javno zdravlje u Nišu, Niš, Srbija \\ ${ }^{4}$ Univerzitet u Nišu, Medicinski fakultet, Niš, Srbija \\ Kontakt: Miljana Džunić \\ Bulevar dr Zorana Đinđića 48, 18000 Niš, Srbija \\ E-mail: drmdzunic@gmail.com
}

Cilj rada je definisati prediktivne faktore za terapijski odgovor i rani relaps nakon resekcije jetre kod bolesnika koji su primili preoperativnu konverzionu terapiju FOLFOX4 i bevacizumab zbog metastaza kolorektalnog karcinoma u jetri.

Ova opservaciona retrospektivna analiza uključila je šezdeset pet bolesnika koji su lečeni FOLFOX4 i bevacizumab režimom, usled potencijalno resektabilnih metastaza kolorektalnog karcinoma u jetri. Bolesnici su podeljeni u grupe na osnovu objektivnog terapijskog odgovora. Izdvojene su grupe sa ranim ( $\leq 3$ meseca) i kasnim ( $\geq 12$ meseci) relapsom nakon resekcije jetre. Među ovim grupama analizirane su karakteristike bolesti i rađene su univarijantna i multivarijantna analiza.

Nezavisni faktor rizika za izostanak terapijskog odgovora bila je lokalizacija tumora na rektumu (OR 3,86 [95\% CI 1,31-11,34]; $p=0,014$ ). Lokalizacija tumora na levom kolonu bila je nezavisni protektivni faktor za izostanak terapijskog odgovora (OR 0,205 [95\% CI $0,05-0,80] ; p=0,022$ ). Nezavisni prediktori za rani relaps bili su sinhrone jetrene metastaze (OR 18 [95\% CI 2,47-131,28]; $\mathrm{p}=0$,004) i broj metastaza (OR 2,42 [95 \% CI 1,14-5,01]; p $=0,021)$. U multivarijantnom modelu statističku značajnost imala je samo sinhrona bolest jetre (OR 13,79 [95\% CI 1,54-123,77]; $p=0,019$ ).

Lokalizacija primarnog tumora na levom kolonu prediktor je odgovora na terapiju, a karcinom rektuma povezan je sa odsustvom odgovora na terapiju bevacizumab i FOLFOX4. Nezavisni faktori rizika za rani relaps nakon resekcije jetre su veći broj metastaza i sinhrono zahvatanje jetre.

Acta Medica Medianae 2019;58(3):72-79.

KIjučne reči: kolorektalni karcinom, metastaze, jetra, prediktori 